Article

\title{
Enhancement of Biomass and Calcium Carbonate Biomineralization of Chlorella vulgaris through Plackett-Burman Screening and Box-Behnken Optimization Approach
}

\author{
Zheng Wei Chin ${ }^{1}$, Kavithraashree Arumugam ${ }^{1}$, Siti Efliza Ashari ${ }^{2,3}$, \\ Fadzlie Wong Faizal Wong ${ }^{1,3}$, Joo Shun Tan ${ }^{3,4}$, Arbakariya Bin Ariff ${ }^{1,3}$ and \\ Mohd Shamzi Mohamed 1,3,*(D) \\ 1 Department of Bioprocess Technology, Faculty of Biotechnology, Universiti Putra Malaysia, UPM, \\ Serdang 43400, Selangor, Malaysia; jackczw@gmail.com (Z.W.C.); kavithraashree@gmail.com (K.A.); \\ fadzlie@upm.edu.my (F.W.F.W.); arbarif@upm.edu.my (A.B.A.) \\ 2 Department of Chemistry, Faculty of Science, Universiti Putra Malaysia, UPM, Serdang 43400, \\ Selangor, Malaysia; ctefliza@upm.edu.my \\ 3 Bioprocessing and Biomanufacturing Research Centre, Universiti Putra Malaysia, UPM, Serdang 43400, \\ Selangor, Malaysia; jooshun@usm.my \\ 4 Bioprocess Technology, School of Industrial Technology, Universiti Sains Malaysia, Gelugor 11800, \\ Pulau Pinang, Malaysia \\ * Correspondence: m_shamzi@upm.edu.my
}

Received: 26 May 2020; Accepted: 20 June 2020; Published: 28 July 2020

\begin{abstract}
The biosynthesis of calcium carbonate $\left(\mathrm{CaCO}_{3}\right)$ minerals through a metabolic process known as microbially induced calcium carbonate precipitation (MICP) between diverse microorganisms, and organic/inorganic compounds within their immediate microenvironment, gives rise to a cementitious biomaterial that may emerge as a promissory alternative to conventional cement. Among photosynthetic microalgae, Chlorella vulgaris has been identified as one of the species capable of undergoing such activity in nature. In this study, response surface technique was employed to ascertain the optimum condition for the enhancement of biomass and $\mathrm{CaCO}_{3}$ precipitation of C. vulgaris when cultured in Blue-Green (BG)- 11 aquaculture medium. Preliminary screening via Plackett-Burman Design showed that sodium nitrate $\left(\mathrm{NaNO}_{3}\right)$, sodium acetate, and urea have a significant effect on both target responses $(p<0.05)$. Further refinement was conducted using Box-Behnken Design based on these three factors. The highest production of $1.517 \mathrm{~g} / \mathrm{L}$ C. vulgaris biomass and $1.143 \mathrm{~g} / \mathrm{L}$ of $\mathrm{CaCO}_{3}$ precipitates was achieved with a final recipe comprising of $8.74 \mathrm{mM}$ of $\mathrm{NaNO}_{3}, 61.40 \mathrm{mM}$ of sodium acetate and $0.143 \mathrm{~g} / \mathrm{L}$ of urea, respectively. Moreover, polymorphism analyses on the collected minerals through morphological examination via scanning electron microscopy and crystallographic elucidation by X-ray diffraction indicated to predominantly calcite crystalline structure.
\end{abstract}

Keywords: Chlorella vulgaris; Box-Behnken Design; Plackett-Burman Design; Biomass; Calcium Carbonate; Biomineralization; Response Surface Methodology

\section{Introduction}

The advancement in today's bioprocessing technologies has seen microalgae soared in values. Their lipids, peptides, polysaccharides, and other bioactive compounds are now the essential components in different products of cosmeceutical, pharmaceutical, and nutraceutical industries owing to their antioxidant, antihypertensive, and anti-inflammatory properties [1]. Another emerging area 
that could tap onto microalgal diversity originates from the biomineralogy concept of microbiological activity inducing calcium carbonate $\left(\mathrm{CaCO}_{3}\right)$ crystals formation. The resulting crystals can either act as cementing agencies between sand grains that further increases the shear strength of soils, or by filling in the pores in-between aggregates to reduce the water conductivity [2].

Numerous microorganisms participate in the so-called microbially induced calcium carbonate precipitation (MICP) in various environments. MICP has the potential to become a sustainable source of biocement since the conventional method of producing Portland cement brings negative impacts in the form of high energy consumption and $\mathrm{CO}_{2}$ emissions. By comparison, MICP process occurs at ambient temperature, a stark contrast to an ordinary sandstone production which needs the temperature to be $1500{ }^{\circ} \mathrm{C}$, and it requires a much shorter period for the full strength to develop as opposed to 28 days for standard cement [3].

Established pathways leading to $\mathrm{CaCO}_{3}$ precipitation include urea hydrolysis, photosynthesis, dissimilatory sulfate reduction, ammonification of amino acids, and denitrification. Biomineralization by ureolytic bacteria has received most of the attention so far, possibly due to the highest $\mathrm{CaCO}_{3}$ conversion efficiency as compared to other processes coupled with the straightforward and easily controlled reaction [4]. Microalgae, on the other hand, are fascinating candidates for MICP process. Besides harboring urease enzymes, they are capable of inducing biomineralization through photosynthesis pathway as well. Geomicrobiological field surveys and laboratory experiments on $\mathrm{CaCO}_{3}$ deposition has revealed biomineralization activity of phylum Chlorophyta, Bacillariophyta, and Cyanophyta [5-7].

The presence of calcium ions, dissolved inorganic carbon (DIC) (mainly in the form of $\mathrm{HCO}_{3}^{-}$ions), alkaline $\mathrm{pH}$, and availability of the nucleation sites govern the MICP activity. Urea concentration may directly affect the $\mathrm{CaCO}_{3}$ precipitated through urea hydrolysis pathway. Nonetheless, since microalgae are the biomineralization agent in question, calcification may also proceed through $\mathrm{HCO}_{3}^{-}$and $\mathrm{CO}_{3}^{2-}$ exchange during photosynthesis [8]. Most microalgae are photoautotrophs harnessing $\mathrm{CO}_{2}$ as their primary carbon source. Typical drawbacks of photoautotrophic cultures are usually related to the microalgae requirement for light, slow growth rate and low biomass yield [9].

Biomass density though significantly improved for species that can uptake other carbon sources. In this sense, mixotrophic microalgae hold more advantage against obligate photoautotrophs, benefitting from solar energy to drive the primary energy route while simultaneously able to assimilate both organic carbon and $\mathrm{CO}_{2}$ in the medium. This 'photo-heterotrophy' trait is only manifested in several species. Chlorella, for instance, the switch to the mixotrophic or strict heterotrophic mode when supplemented with glucose, glycerol or acetate is thoroughly established [10]. Trophic manipulation of this genus for large scale biomass and photosynthetic metabolites production have been commonly cited over the past three decades [11].

Besides improving biomass density, prevalent investigations on Chlorella vulgaris in the past seek to evaluate its feasibility toward accumulating soluble carbohydrates and lipids as raw material for biofuel applications [12]. To date, available studies on MICP process mediated by C. vulgaris deals with trophic comparison [13], calcification enhancement through $\mathrm{CO}_{2}$ sequestration in raceway pond [5], utilization of $\mathrm{Ca}^{2+}$ and $\mathrm{HCO}_{3}^{-}$ions from karst water [14], and co-cultivation strategy between Chlorella-Sporosarcina pasteurii, a $\mathrm{CaCO}_{3}$ precipitation inducer bacterium [15]. At present, no study is focusing on establishing cultural conditions that concurrently promotes substantial biomass growth and $\mathrm{CaCO}_{3}$ precipitation by C. vulgaris strain.

Design of experiment (DoE) employing statistical techniques is quite popular in many scenarios as it accorded the experimenters a facility to systematically screen for effectors, setting up predictive models and optimizing the process with a minimum number of runs. Plackett-Burman design (PBD) is a classical two-level fractional factorial method for identifying critical parameters from $N$ variables running $N+1$ number of experiments. On the other hand, Box-Behnken design (BBD) is a rotatable response surface technique distinguished by three-levels per factor applied to independent variables that were selected from screening exercise. This study utilized both PBD and BBD method to derive 
statistically fitted models describing the effects and interactions between factors that constitute the common Blue-Green (BG)-11 aquaculture medium towards enhancing biomass density and $\mathrm{CaCO}_{3}$ biomineralization performance of local C. vulgaris in shake flask system.

\section{Results and Discussion}

\subsection{Screening of Significant Factors Through Plackett Burman Design (PBD)}

Screening is a prelude to optimization experiments and is a crucial step to eliminate any insignificant factors or noise, ensuring that favorable conditions are met for the growth of $C$. vulgaris and accumulation of the product of interest. PBD is usually employed for ruggedness testing based on the multiplication of four (rather than a power of two) number of factorials which would result in small-sized runs emphasizing on determining the most significant main effects without recourse to the interaction between factors. Since the PBD option in Design Expert DoE software package allows for a minimum of eleven experimental variables, this study utilized eight-actual and three-dummy factors to initiate the screening process. PBD comprising of 14 runs were performed, which also included two center point replicates to obtain an estimate of pure error. PBD matrices showing the levels of each factor in their actual values with the corresponding biomass density and weight of $\mathrm{CaCO}_{3}$ precipitates are shown in Table 1.

Table 1. Plackett-Burman Design of eight factors in actual levels with predicted and observed values of $C$. vulgaris biomass density and $\mathrm{CaCO}_{3}$ precipitates.

\begin{tabular}{|c|c|c|c|c|c|c|c|c|c|c|c|c|}
\hline \multirow{2}{*}{ No. } & \multicolumn{8}{|c|}{ Factors } & \multicolumn{2}{|c|}{ Biomass (g/L) } & \multicolumn{2}{|c|}{$\mathrm{CaCO}_{3}(\mathrm{~g} / \mathrm{L})$} \\
\hline & $A$ & $B$ & $C$ & $D$ & $E$ & $F$ & $G$ & $H$ & Predicted & Observed & Predicted & Observed \\
\hline 1 & 22.00 & 0.100 & 0.020 & 0.1 & 0.07 & 7.50 & 30 & 0.05 & 0.87 & 0.85 & 0.361 & 0.389 \\
\hline 2 & 22.00 & 0.100 & 0.00077 & 0.1 & 0.07 & 50.00 & 24 & 30.00 & 1.00 & 1.00 & 0.694 & 0.655 \\
\hline 3 & 2.50 & 0.100 & 0.020 & 0.1 & 0.33 & 50.00 & 30 & 0.05 & 1.25 & 1.20 & 0.652 & 0.624 \\
\hline 4 & 22.00 & 0.010 & 0.00077 & 0.1 & 0.33 & 7.50 & 30 & 30.00 & 0.60 & 0.50 & 0.206 & 0.190 \\
\hline 5 & 22.00 & 0.010 & 0.020 & 1.5 & 0.07 & 50.00 & 30 & 30.00 & 0.85 & 0.90 & 0.561 & 0.588 \\
\hline 6 & 12.25 & 0.055 & 0.01038 & 0.8 & 0.20 & 28.75 & 27 & 15.03 & 1.05 & 1.10 & 0.583 & 0.598 \\
\hline 7 & 2.50 & 0.010 & 0.020 & 0.1 & 0.33 & 50.00 & 24 & 30.00 & 0.98 & 1.00 & 0.625 & 0.654 \\
\hline 8 & 22.00 & 0.100 & 0.00077 & 1.5 & 0.33 & 50.00 & 24 & 0.05 & 1.12 & 1.20 & 0.756 & 0.795 \\
\hline 9 & 2.50 & 0.100 & 0.00077 & 1.5 & 0.33 & 7.50 & 31 & 30.00 & 1.25 & 1.30 & 0.703 & 0.720 \\
\hline 10 & 2.50 & 0.100 & 0.020 & 1.5 & 0.07 & 7.50 & 24 & 30.00 & 1.25 & 1.20 & 0.830 & 0.813 \\
\hline 11 & 2.50 & 0.010 & 0.00077 & 1.5 & 0.07 & 50.00 & 30 & 0.05 & 1.10 & 1.00 & 0.717 & 0.690 \\
\hline 12 & 22.00 & 0.010 & 0.020 & 1.5 & 0.33 & 7.50 & 24 & 0.05 & 0.72 & 0.70 & 0.396 & 0.356 \\
\hline 13 & 2.50 & 0.010 & 0.00077 & 0.1 & 0.07 & 7.50 & 24 & 0.05 & 0.85 & 1.00 & 0.490 & 0.517 \\
\hline 14 & 12.25 & 0.055 & 0.01038 & 0.8 & 0.20 & 28.75 & 27 & 15.03 & 1.05 & 1.00 & 0.583 & 0.568 \\
\hline
\end{tabular}

Results from PBD experiments were then fitted to the linear first-order model as explained in the Materials and Method section (Equation (4)) with model adequacy for each of the response being subjected to analysis of variance (ANOVA). Initially, by accounting all eight factors $(A-H)$ in a full model, some of the regression coefficients were found to produce individual $p$-values of $>0.05$. In turn, these contributed to the full model itself to be insignificant for interpreting the data. Backward elimination procedure was then carried out to exclude any unnecessary model terms one at a time, starting with the term having the highest $p$-value. Elimination stopped when only factors with $p$-values below 0.05 were left in the model, resulting in an overall significant but reduced model.

The analysis of variance performed on the reduced models for C. vulgaris biomass density (Table 2) and $\mathrm{CaCO}_{3}$ precipitation (Table 3) has demonstrated that the models are statistically valid with $p$-values of 0.0007 and 0.0005 , respectively. In other words, by looking at the corresponding $F$-value, which practically measures the ratio of between-groups variance to the within-groups variance of treatments, at 16.08 and 19.82 , they would imply that both models are highly significant. There is only $0.07 \%$ and $0.05 \%$ chance that "Model F-value" could have occurred due to noise. 
Table 2. ANOVA of the reduced model from Plackett-Burman design (PBD) screening for C. vulgaris biomass density.

\begin{tabular}{cccccc}
\hline Source & Sum of Squares & df & Mean Square & F-Value & $p$-Value \\
\hline Model & 0.5208 & 4 & 0.1302 & 16.08 & 0.0007 \\
A-Sodium nitrate & 0.2002 & 1 & 0.2002 & 24.72 & 0.0011 \\
B-Urea & 0.2269 & 1 & 0.2269 & 28.01 & 0.0007 \\
D-Magnesium sulfate & 0.0469 & 1 & 0.0469 & 5.79 & 0.0428 \\
F-Sodium acetate & 0.0469 & 1 & 0.0469 & 5.79 & 0.0428 \\
Curvature & 0.0067 & 1 & 0.0067 & 0.8268 & 0.3898 \\
Residual & 0.0648 & 8 & 0.0081 & & \\
Lack of Fit & 0.0598 & 7 & 0.0085 & 1.71 & 0.5308 \\
Pure Error & 0.0050 & 1 & 0.0050 & & \\
Corrected Total & 0.5923 & 13 & & & \\
\hline
\end{tabular}

Model summary: $R^{2}=0.8894$; Coefficient of Variation (C.V.) $=9.03 \%$; Adjusted- $R^{2}$ (Adj- $R^{2}$ ) $=0.8340$; Predicted- $R^{2}$ $\left(\right.$ Pred- $\left.\mathrm{R}^{2}\right)=0.6658 ; \mathrm{df}$, degrees of freedom

Table 3. ANOVA of the reduced model from PBD screening for $\mathrm{CaCO}_{3}$ precipitates concentration.

\begin{tabular}{cccccc}
\hline Source & Sum of Squares & df & Mean Square & F-Value & $p$-Value \\
\hline Model & 0.36 & 5 & 0.073 & 19.82 & 0.0005 \\
A-Sodium nitrate & 0.091 & 1 & 0.091 & 24.77 & 0.0016 \\
B-Urea & 0.084 & 1 & 0.084 & 22.82 & 0.0020 \\
D-Magnesium sulfate & 0.073 & 1 & 0.073 & 19.88 & 0.0029 \\
F-Sodium acetate & 0.087 & 1 & 0.087 & 23.72 & 0.0018 \\
G-Temperature & 0.029 & 1 & 0.029 & 7.91 & 0.0260 \\
Curvature & $5.131 \times 10^{-8}$ & 1 & $5.131 \times 10^{-8}$ & $1.401 \times 10^{-5}$ & 0.9971 \\
Residual & 0.026 & 7 & $3.661 \times 10^{-3}$ & & 0.2425 \\
Lack of Fit & 0.025 & 6 & $4.198 \times 10^{-3}$ & 9.57 & \\
Pure Error & $4.387 \times 10^{-4}$ & 1 & $4.387 \times 10^{-4}$ & & \\
Corrected Total & 0.39 & 13 & & &
\end{tabular}

Model summary: $R^{2}=0.9340 ;$ C.V. $=9.72 \%$; Adj- $R^{2}=0.8928$; Pred- $R^{2}=0.7512$.

The goodness of fit of these models is indicated by the coefficient of determination $\left(R^{2}\right)$. The respectable $R^{2}$ value for microalgal biomass density model at 0.8894 , and $R^{2}$ describing $\mathrm{CaCO}_{3}$ precipitation model at 0.9340 indicate that $88.94 \%$ and $93.40 \%$ of the variability in the two responses could be explained by the models, signifying good agreement between experimental and predicted values. Following backwards elimination results of Tables 2 and 3, factors that posed significant effect $(p<0.05)$ towards promoting $C$. vulgaris biomass density are $\mathrm{NaNO}_{3}$, urea, $\mathrm{MgSO}_{4} .7 \mathrm{H}_{2} \mathrm{O}$ and sodium acetate $(A, B, D, F)$. Factors that are decidedly influencing the biomineralization of $\mathrm{CaCO}_{3}$ precipitates are likewise, $\mathrm{NaNO}_{3}$, urea, $\mathrm{MgSO}_{4} \cdot 7 \mathrm{H}_{2} \mathrm{O}$, and sodium acetate with an addition of exogenous factor of temperature $(A, B, D, F, G)$.

The positive and negative effects of each factor influencing $C$. vulgaris biomass and $\mathrm{CaCO}_{3}$ precipitation is also depicted in Figure 1. A negative value in the bar chart indicates that the shift of the factor from low level to the high level produced a decreased in biomass or $\mathrm{CaCO}_{3}$ precipitation, while a positive value means that the changes in a level increase such responses. Regarding the examined levels, it is apparent that urea was the most significant factor in positively enhanced microalga growth. Observation of the actual results in Table 1 points to urea providing a roughly 2.6-fold increase in biomass density when furnished with concentration ranges from $0.01 \mathrm{~g} / \mathrm{L}$ to $0.1 \mathrm{~g} / \mathrm{L}$ (standardized effect of 0.275 ), followed equally by sodium acetate and $\mathrm{MgSO}_{4} \cdot 7 \mathrm{H}_{2} \mathrm{O}$ (both at 0.125 ). The highest effector that negates growth is shown to be $\mathrm{NaNO}_{3}(-0.258)$. Temperature (-0.058), $\mathrm{ZnSO}_{4} \cdot 7 \mathrm{H}_{2} \mathrm{O}(-0.025)$ and $\mathrm{K}_{2} \mathrm{HPO}_{4}(-0.008)$ are less likely to impart significant effect on $C$. vulgaris biomass density. 


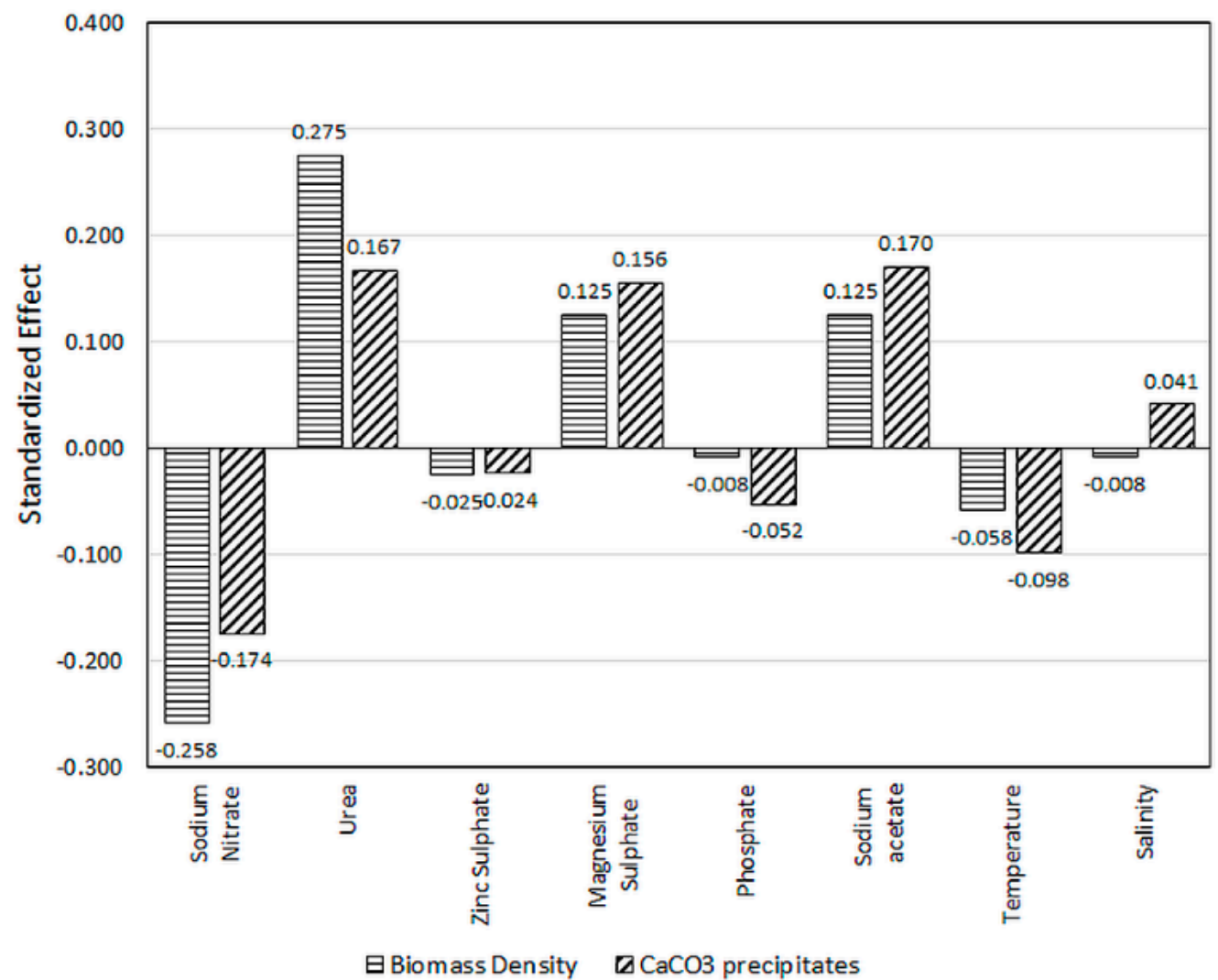

Figure 1. Effect of different factors on biomass density and $\mathrm{CaCO}_{3}$ precipitates concentration.

The improvement in the MICP activity of $C$. vulgaris mostly paralleled the gain in biomass since all the factors in Figure 1 depict identical synergistic or antagonistic effects towards $\mathrm{CaCO}_{3}$ precipitation except for salinity $(H)$. Based on the standardized effect values, the positive effect is mostly attributed to sodium acetate (0.170), followed closely by urea (0.167), $\mathrm{MgSO}_{4} .7 \mathrm{H}_{2} \mathrm{O}(0.156)$ and to a lesser degree, salinity (0.041). Factors that registered in reduced biomineralization are $\mathrm{NaNO}_{3}(-0.174)$, temperature $(-0.098), \mathrm{K}_{2} \mathrm{HPO}_{4}(-0.052)$, and $\mathrm{ZnSO}_{4} .7 \mathrm{H}_{2} \mathrm{O}(-0.024)$.

As a reduced form of nitrogen source, $C$. vulgaris affinity towards urea as compared to $\mathrm{NaNO}_{3}$ could be due to less energy required by the compound to undergo assimilation process, and it is potentially easier to pass through the plasma membrane of microalgae cells. Hence, lending itself towards a synergistic effect on cell growth [16]. As a viable source of carbon, acetate can be metabolized through two pathways in microalgae, the glyoxylate cycle and the tricarboxylic acid (TCA) cycle. In C. vulgaris, isocitrate lyase, the key enzyme for the assimilation of acetate/acetyl-CoA in the glyoxylate pathway, is synthesized constitutively. However, the glyoxylate cycle is functional only when cells are grown on acetate-containing medium [10]. During the dark period of cultivation, the activity of isocitrate lyase increases sufficiently for glyoxylate cycle to account for the syntheses necessary to maintain growth while enzymes related to TCA cycle are not induced, though the latter pathway remains active. In the event of illumination, citrate synthase, isocitrate dehydrogenase, and succinyl-CoA synthetase, which provide intermediate metabolites of the TCA cycle, are then upregulated in mixotrophic cultivation. Chlorella cells metabolizing acetate would go on to increase the incorporation of carbon into the cellular components, particularly into lipid, polysaccharide, and protein [17]. Magnesium is one of the essential macronutrients required for growth as it forms the central atom of a chlorophyll molecule for microalgal photosynthesis. It means that, for every one molecule of chlorophyll produced, one $\mathrm{Mg}^{2+}$ is required [18].

On the flip side, $\mathrm{NaNO}_{3}$ exerts a significant antagonistic effect on the biomass of $C$. vulgaris. PBD simulation in this study predicted that the biomass density gradually reduced from $1.12 \mathrm{~g} / \mathrm{L}$ to $0.86 \mathrm{~g} / \mathrm{L}$ with the increasing $\mathrm{NaNO}_{3}$ concentration in medium from $2.5 \mathrm{mM}$ to $22 \mathrm{mM}$. In Soil Extract (S.E.) 
medium supplemented with $10 \mathrm{~g} / \mathrm{L}$ glucose, Xie et al. [19] observed that nitrate had outperformed ammonium, peptone, and yeast extract, and slightly edging urea in supporting $C$. vulgaris growth. Interestingly, the authors reported that even though low nitrate concentrations $(<1.00 \mathrm{~g} / \mathrm{L})$ would result in $C$. vulgaris reaching stationary phase much earlier, the growth behaviour bore a similarity to culture fed with high nitrate concentrations $(\approx 2.00 \mathrm{~g} / \mathrm{L})$. In their study, nitrate concentration in the region of $12 \mathrm{mM}(\approx 1 \mathrm{~g} / \mathrm{L})$ was suggested as critical concentration for sufficient nitrogen supply in which excess nitrogen could not be utilized by $C$. vulgaris above this limit, indicating that luxury uptake of nitrogen was not apparent.

The synergistic effect of introducing acetate and urea as supplementary carbon and nitrogen source also points to the significance of growth under alternative metabolic conditions potentially enhancing the carbonate precipitation. By looking at the concomitant increase in both biomass and $\mathrm{CaCO}_{3}$ precipitates, one can deduce that higher biomass would translate to higher availability of the cell surface structure for nucleation to take place. Besides the apparent increase in cell numbers, sodium acetate assimilation also produces relatively larger cells. Mixotrophic acetate feeding by Chlorella pyrenoidosa had evolved the cells exhibiting a mean diameter of $11.8 \mu \mathrm{m}$ against $8.0 \mu \mathrm{m}$ for normal photoautotrophic cells [17].

Notwithstanding that the role of mixotrophic mode upon $\mathrm{CaCO}_{3}$ precipitation by $\mathrm{C}$. vulgaris was not directly tackled in the past, the effect of trophic switching in term of carbonate precipitation rate was evaluated in one study by Kawano et al. [13]. In their experiment, having utilized $5 \mathrm{mM}$ $\mathrm{CaCl}_{2}$ and $20 \mathrm{mM} \mathrm{NaHCO}_{3}$ containing-medium, it was recognized that the $\mathrm{CaCO}_{3}$ precipitation rate of the biotic system (addition of $10^{6}$ cells $/ \mathrm{mL} \mathrm{C}$. vulgaris microalga) under illumination had posted considerably higher values of 2.7-2.9 enhancement factor over baseline abiotic system owing to the photosynthetic activity of $C$. vulgaris. In contrast, the biotic system under dark condition (C. vulgaris grew in heterotrophic mode) registered lower biomineralization rate than those of the abiotic system, with an inhibition factor of about 0.8-0.9. The marked reduction in precipitation between the two trophic systems was related to the interaction of different organic molecules released from the cells of C. vulgaris with the $\mathrm{CaCO}_{3}$ mineral surfaces.

\subsection{Selection of Significant Factors for Further Optimization}

The experimental factors were assigned in such a way that they would be simultaneously become significant to both responses. Screening criteria considered the degree of their contribution (expressed in percentages) and the corresponding statistical significances, evidencing in $p$-values of less than 0.05 from $\mathrm{PBD}$ results. Evidently from Tables 2 and 3, both the biomass density and $\mathrm{CaCO}_{3}$ precipitates were highly affected by $\mathrm{NaNO}_{3}$, urea, $\mathrm{MgSO}_{4} .7 \mathrm{H}_{2} \mathrm{O}$ and sodium acetate concentrations. The percentage contribution of the different tested factors depicted in Figure 2 shows that all four accounted for nearly $88 \%$ of the total effect exerted on biomass production and about $86 \%$ towards carbonate precipitation. Only the top three most significant factors would be chosen for further optimization; an economic decision made based on the experimental duration and availability of experimental resources. A four-factor response surface BBD design would have created 29 runs, resulting in a considerably large total runs (58) if duplication were considered for each run. 


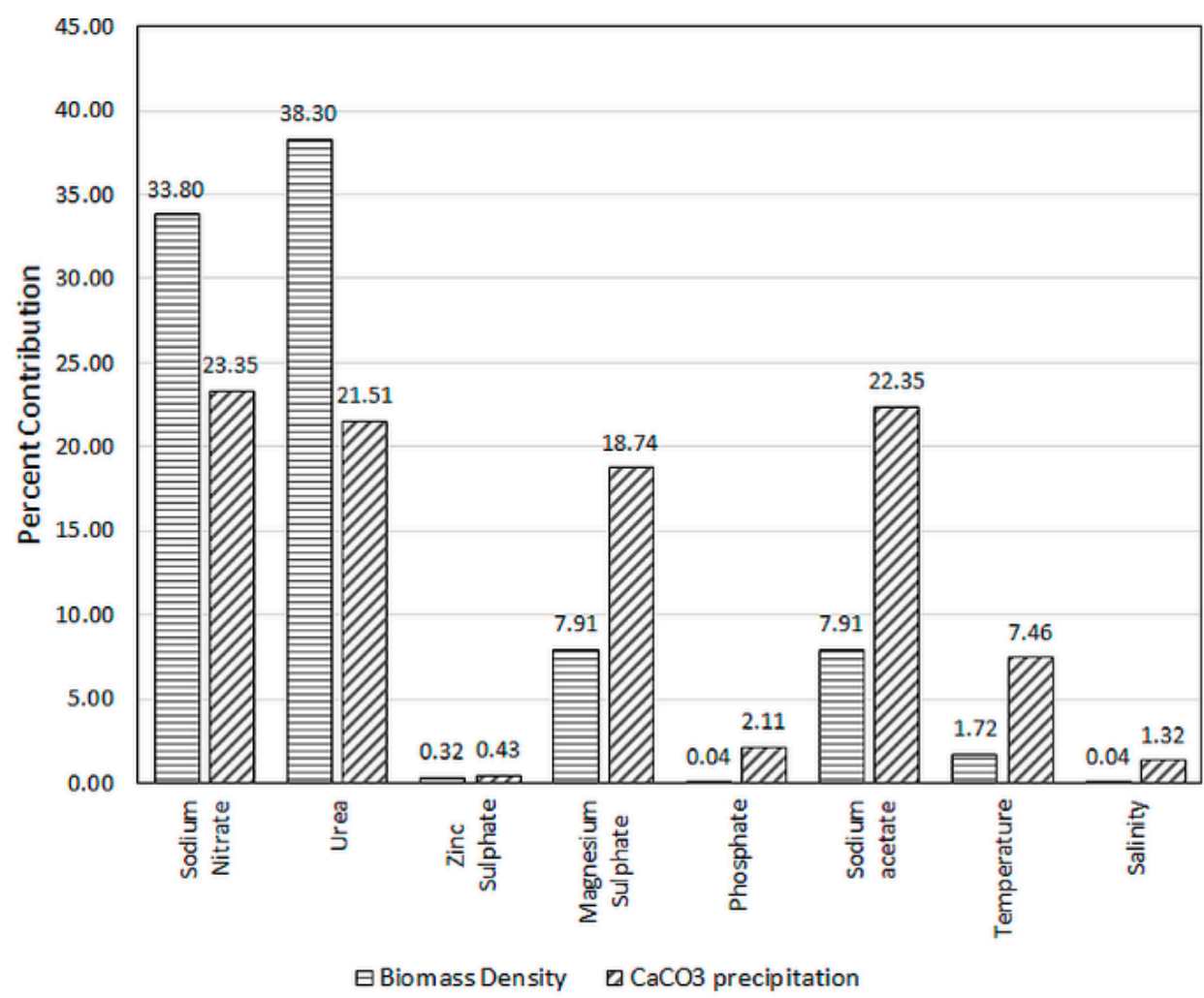

Figure 2. Percent contribution of different factors on biomass density and $\mathrm{CaCO}_{3}$ precipitates concentration.

$\mathrm{NaNO}_{3}$ and urea were straightforward choices due to them collectively possessing $72 \%$ effect on cell growth and $45 \%$ towards MICP activity. The two medium components also exhibit explicitly small $p$-values in both ANOVA tables. Between $\mathrm{MgSO}_{4} \cdot 7 \mathrm{H}_{2} \mathrm{O}$ and sodium acetate, both recorded similar $p$-value of 0.0428 and equally contributed to about $7.91 \%$ of individual effect towards biomass density. Nonetheless, biomineralization by $C$. vulgaris proved far sensitive to changes in sodium acetate concentration, judging from the $22.35 \%$ of effect exertion by the compound as opposed to $18.74 \%$ contribution by $\mathrm{MgSO}_{4} \cdot 7 \mathrm{H}_{2} \mathrm{O}$. As such, this effective rounded up the variable selection process and three factors $\left(\mathrm{NaNO}_{3}\right.$, urea, and sodium acetate) were chosen for the second statistical step of Box-Behnken Design to realize the main effects and possible interactions among them. As the number of factors was reduced from eight to three, the concentrations of other non-significant factors were held at their respective PBD center point values in the following medium optimization study.

\subsection{Optimization via Box-Behnken Design (BBD)}

The motivation of choosing BBD instead of the more popular central composite rotatable design (CCRD) lies in the economy of experiments as it can generate fewer runs, as well as avoiding treatment combinations that may sit on the extreme points of the experiment boundaries [20]. Seventeen experimental runs with five center points were generated for the three-level BBD investigation on the combined effect of $\mathrm{NaNO}_{3}(A)$, sodium acetate $(B)$ and urea $(C)$ on biomass density and carbonate precipitation. Table 4 shows the experimental conditions complete with the predicted and corresponding actual results according to the factorial design. The total number of actual experiments were doubled as each standard order runs were an average of duplicates. The levels of each independent variable were determined based on the earlier PBD experiments. The center points (0) of BBD were set as equivalent to optimum values predicted by Design Expert based on PBD dataset. The previous simulation had predicted that a modified BG-11 medium composed of $9.00 \mathrm{mM} \mathrm{NaNO}_{3}, 50.00 \mathrm{mM}$ sodium acetate and $0.125 \mathrm{~g} / \mathrm{L}$ urea would hypothetically maximize the target responses with desirability as high as 0.868 . 
The low and high BBD level (designated as -1 and +1 ) for each of the factor was adjusted appropriately as multiples of the respective center points.

Table 4. Three-factor Box-Behnken Design (BBD) with factorial levels shown in actual values as well as predicted and observed biomass density and $\mathrm{CaCO}_{3}$ precipitates concentration.

\begin{tabular}{|c|c|c|c|c|c|c|c|}
\hline \multirow{2}{*}{$\begin{array}{l}\text { Run } \\
\text { Order }\end{array}$} & \multirow{2}{*}{$\mathrm{NaNO}_{3}(\mathrm{mM})$} & \multirow{2}{*}{$\begin{array}{c}\text { Sodium } \\
\text { Acetate }(\mathrm{mM})\end{array}$} & \multirow{2}{*}{ Urea $(g / L)$} & \multicolumn{2}{|c|}{ Biomass Density (g/L) } & \multicolumn{2}{|c|}{$\mathrm{CaCO}_{3}$ Precipitates $(\mathrm{g} / \mathrm{L})$} \\
\hline & & & & Predicted & Observed & Predicted & Observed \\
\hline 1 & 9 & 50 & 0.125 & 1.49 & 1.50 & 1.121 & 1.162 \\
\hline 2 & 9 & 25 & 0.200 & 1.15 & 1.10 & 0.784 & 0.824 \\
\hline 3 & 12 & 50 & 0.050 & 0.91 & 0.85 & 0.654 & 0.648 \\
\hline 4 & 12 & 25 & 0.125 & 1.01 & 1.10 & 0.759 & 0.796 \\
\hline 5 & 12 & 50 & 0.200 & 0.94 & 0.90 & 0.988 & 0.910 \\
\hline 6 & 12 & 75 & 0.125 & 1.04 & 1.05 & 0.997 & 1.043 \\
\hline 7 & 9 & 75 & 0.200 & 1.26 & 1.30 & 1.072 & 1.103 \\
\hline 8 & 9 & 75 & 0.050 & 1.30 & 1.35 & 0.728 & 0.688 \\
\hline 9 & 6 & 50 & 0.050 & 1.06 & 1.10 & 0.634 & 0.712 \\
\hline 10 & 9 & 50 & 0.125 & 1.49 & 1.55 & 1.121 & 1.135 \\
\hline 11 & 6 & 50 & 0.200 & 1.29 & 1.35 & 0.775 & 0.781 \\
\hline 12 & 9 & 50 & 0.125 & 1.49 & 1.50 & 1.121 & 1.133 \\
\hline 13 & 9 & 25 & 0.050 & 0.84 & 0.80 & 0.653 & 0.622 \\
\hline 14 & 6 & 75 & 0.125 & 1.54 & 1.45 & 0.824 & 0.787 \\
\hline 15 & 9 & 50 & 0.125 & 1.49 & 1.43 & 1.121 & 1.117 \\
\hline 16 & 6 & 25 & 0.125 & 1.01 & 1.00 & 0.699 & 0.652 \\
\hline 17 & 9 & 50 & 0.125 & 1.49 & 1.45 & 1.121 & 1.056 \\
\hline
\end{tabular}

By applying multiple linear regression, data fitting of BBD results to Equation (6) from the Materials and Methods Section has generated the following correlations in terms of un-coded values:

$$
\begin{gathered}
\text { Cell biomass }(g / L)=-2.8515+0.4919 A+0.0464 B+15.1944 C-0.0017 A B-0.0222 A^{2}-0.0002 B^{2}-39.7778 C^{2} \\
\mathrm{CaCO}_{3} \text { concentration }(g / L)=-1.4309+0.3215 A+0.0171 B+6.4100 C-0.0193 A^{2}-0.0002 B^{2}-32.7200 C^{2}
\end{gathered}
$$

The $p$-values from ANOVA analysis conducted on the second-order polynomial model terms were used as a tool to gauge the significance of each coefficient, which also indicated the strength of interaction of each parameter. Smaller $p$-values point to higher significances of the corresponding coefficients. Based on Tables 5 and 6, both models were highly significant to describe the experiments, as indicated by $p$-values of less than 0.0008 . The lack-of-fit was used as a support test for the adequacy of the fitted models. Both regression models show an insignificant lack-of-fit ( $p=0.0770$ for biomass and $p=0.0725$ for $\mathrm{CaCO}_{3}$ ) demonstrating their insignificance relative to the pure error.

ANOVA of the biomass model shows that all the linear coefficients $(A, B, C)$ proved significant. Contrary to the outcome of PBD analysis, the effect of sodium acetate is now considerably higher than the other two $(p<0.0015)$. The model term $A B$ was also significant, indicating that an interaction between $\mathrm{NaNO}_{3}$ and sodium acetate somehow affected the growth of $C$. vulgaris. All three quadratic coefficients $\left(A^{2}, B^{2}, C^{2}\right)$ were also considered as significant. On the other hand, ANOVA of the regression model for $\mathrm{CaCO}_{3}$ concentration placed a remarkably high significance on urea and the least with $\mathrm{NaNO}_{3}$. The terms $A^{2}, B^{2}$ and $C^{2}$, were equally significant to the precipitation of $\mathrm{CaCO}_{3}$. However, looking at both Equation (1) and (2), the quadratic terms were inferred to exert antagonistic effects on both responses. The absence of cross-product coefficients $A B, A C$, and $B C(p>0.05)$ may lead to the assumption that factors have an additive effect on the $\mathrm{CaCO}_{3}$ precipitation. 
Table 5. ANOVA for the quadratic model of dry cell weight of $C$. vulgaris.

\begin{tabular}{cccccc}
\hline Source & Sum of Squares & df & Mean Square & F-Value & $p$-Value \\
\hline Model & 0.9447 & 9 & 0.1050 & 16.28 & 0.0007 \\
A-Sodium nitrate & 0.1250 & 1 & 0.1250 & 19.39 & 0.0031 \\
B-Sodium acetate & 0.1653 & 1 & 0.1653 & 25.64 & 0.0015 \\
C-Urea & 0.0378 & 1 & 0.0378 & 5.87 & 0.0460 \\
AB & 0.0625 & 1 & 0.0625 & 9.70 & 0.0170 \\
AC & 0.0100 & 1 & 0.0100 & 1.55 & 0.2530 \\
BC & 0.0306 & 1 & 0.0306 & 4.75 & 0.0657 \\
A $^{2}$ & 0.1879 & 1 & 0.1879 & 29.15 & 0.0010 \\
B $^{2}$ & 0.0645 & 1 & 0.0645 & 10.00 & 0.0159 \\
C $^{2}$ & 0.2108 & 1 & 0.2108 & 32.70 & 0.0007 \\
Lesidual & 0.0451 & 7 & 0.0064 & & 0.0770 \\
Pure Error Fit & 0.0356 & 3 & 0.0119 & 5.00 & \\
Corrected total & 0.0095 & 4 & 0.0024 & & \\
\hline
\end{tabular}

Model summary: $R^{2}=0.9544 ;$ C.V. $=6.57 \%$; Adj $-R^{2}=0.8958$; Pred $-R^{2}=0.4092 ;$ Adequate Precision $=11.4689 ; \mathrm{df}$, degrees of freedom.

Table 6. ANOVA for the quadratic model of $\mathrm{CaCO}_{3}$ concentration as precipitated by C. vulgaris.

\begin{tabular}{cccccc}
\hline Source & Sum of Squares & df & Mean Square & F-Value & $p$-Value \\
\hline Model & 0.6057 & 169 & 0.0673 & 15.35 & 0.0008 \\
A-Sodium nitrate & 0.0270 & 1 & 0.0270 & 6.17 & 0.0420 \\
B-Sodium acetate & 0.0661 & 1 & 0.0661 & 15.07 & 0.0060 \\
C-Urea & 0.1123 & 1 & 0.1123 & 25.63 & 0.0015 \\
AB & 0.0031 & 1 & 0.0031 & 0.7154 & 0.4256 \\
AC & 0.0093 & 1 & 0.0093 & 2.12 & 0.1883 \\
BC & 0.0113 & 1 & 0.0113 & 2.59 & 0.1517 \\
A $^{2}$ & 0.1272 & 1 & 0.1272 & 29.01 & 0.0010 \\
B $^{2}$ & 0.0682 & 1 & 0.0682 & 15.57 & 0.0056 \\
C $^{2}$ & 0.1426 & 1 & 0.1426 & 32.54 & 0.0007 \\
Residual & 0.0307 & 7 & 0.0044 & & \\
Lack of Fit & 0.0244 & 3 & 0.0081 & 5.20 & 0.0725 \\
Pure Error & 0.0063 & 4 & 0.0016 & & \\
Corrected total & 0.6364 & 16 & & &
\end{tabular}

Model summary: $R^{2}=0.9518 ;$ C.V. $=7.42 \%$; Adj- $R^{2}=0.8898$; Pred $-R^{2}=0.3706$; Adequate Precision = 9.5752; df, degrees of freedom.

\subsection{Mutual Effects of Factors on Biomass Density and $\mathrm{CaCO}_{3}$ Concentration}

Second-order quadratic polynomial equation regressed to the experimental data can be graphically represented by the surface and contour plot as a function of two factors at a time, while keeping the rest constant at their center point. In the present study, the response surface plots of Figures 3a and $4 a-c$ depict a fully developed circular concave surface, thus suggesting the presence of an apparent optimum condition at the peak. In contrast, Figure 3b,c appear to have elliptical contours. The optimum point in these figures might be located at the top-most edge of the incomplete concave plot or perhaps, slightly outside the design boundary. Contour plots are two-dimensional representations of the response surface, which enhance the visual interpretation of the response surface. Response surface showing elliptical contour suggests significant mutual interactions between the independent variables, whereas a circular contour plot implicates negligible interaction between the corresponding variables [21]. 
(a)

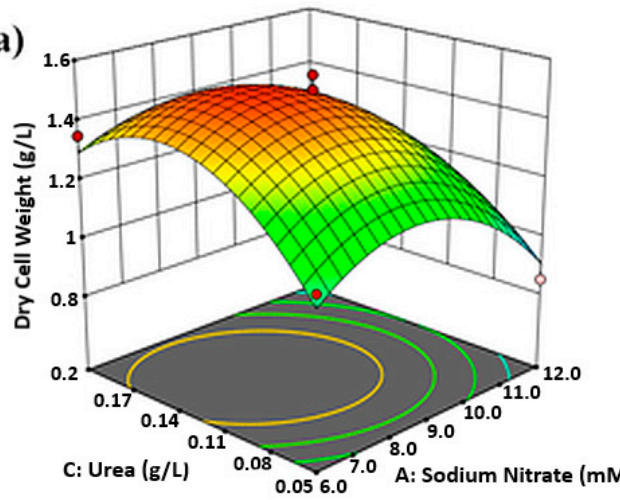

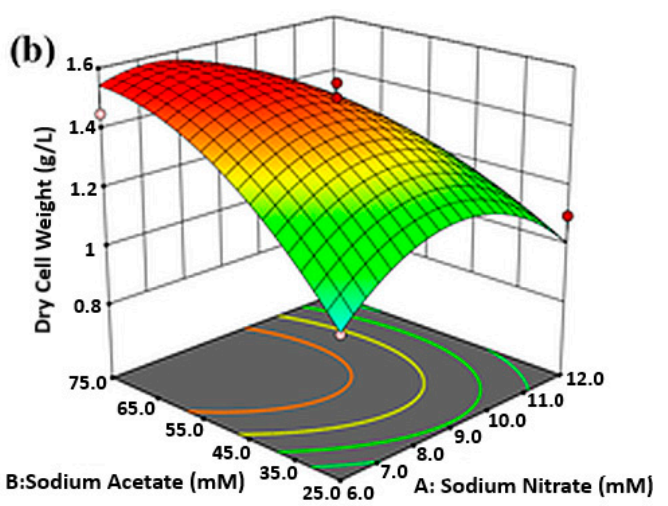

(c)

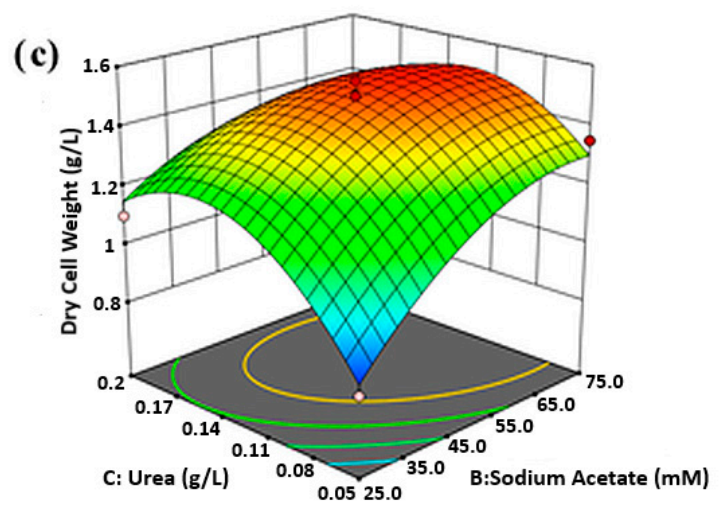

Figure 3. Response surfaces and contour plots showing the mutual effect of (a) urea and $\mathrm{NaNO}_{3}$, (b) sodium acetate and $\mathrm{NaNO}_{3}$, (c) urea and sodium acetate on $\mathrm{C}$. vulgaris biomass density.

(a)

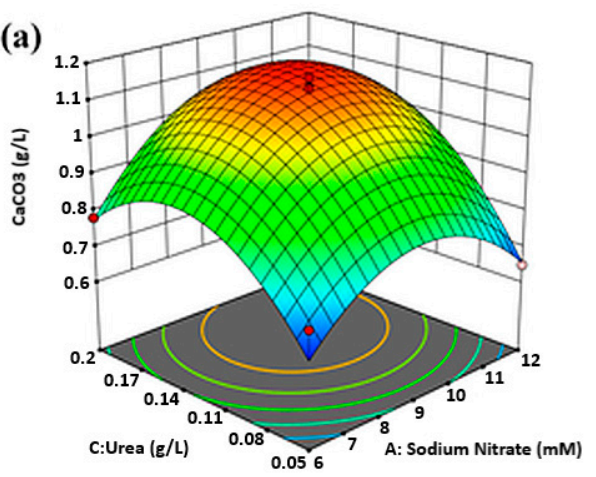

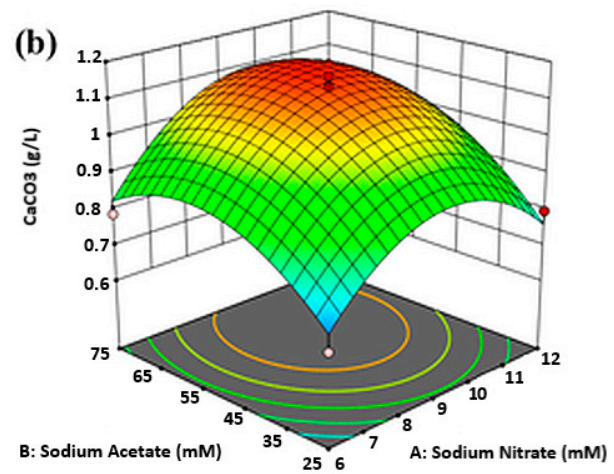

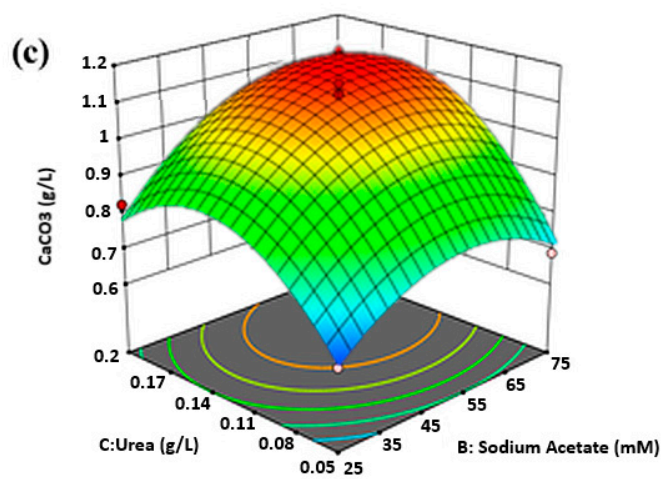

Figure 4. Response surfaces and contour plots showing the mutual effect of (a) urea and $\mathrm{NaNO}_{3}$, (b) sodium acetate and $\mathrm{NaNO}_{3}$, and (c) urea and sodium acetate on $\mathrm{CaCO}_{3}$ precipitates concentration.

According to Figure 3a, the highest biomass density was conceivable when urea was linearly increased to concentration in between $0.125 \mathrm{~g} / \mathrm{L}$ to $0.155 \mathrm{~g} / \mathrm{L}$, with $\mathrm{NaNO}_{3}$ modulated to $7.5 \mathrm{mM}$ to 
$9.0 \mathrm{mM}$, and sodium acetate held at $50 \mathrm{mM}$. Alternatively, Figure $3 \mathrm{~b}$ points to maximum biomass by setting up sodium acetate between $65 \mathrm{mM}$ to $75 \mathrm{mM}$, and $\mathrm{NaNO}_{3}$ from $6.8 \mathrm{mM}$ to $8.5 \mathrm{mM}$, with urea constant at $0.125 \mathrm{~g} / \mathrm{L}$. Figure $3 \mathrm{c}$ then shows that maximum biomass production was also observed when $\mathrm{NaNO}_{3}$ was maintained constant at $9 \mathrm{mM}$, while the sodium acetate concentration was maintained from $61.0 \mathrm{mM}$ to $68.5 \mathrm{mM}$ and urea concentration from $0.120 \mathrm{~g} / \mathrm{L}$ to $0.145 \mathrm{~g} / \mathrm{L}$.

The mutual effects of $\mathrm{NaNO}_{3}$, urea, and sodium acetate on the concentration of $\mathrm{CaCO}_{3}$ precipitates are all shown by the well-defined dome-shaped response surface plots in Figure $4 \mathrm{a}-\mathrm{c}$. The effects of urea, $\mathrm{NaNO}_{3}$ and their reciprocal interactions on $\mathrm{CaCO}_{3}$ precipitation at fixed sodium acetate concentration in Figure 4 a shows that $\mathrm{CaCO}_{3}$ concentration increased in tandem with urea and $\mathrm{NaNO}_{3}$ increasing. By keeping the concentration of sodium acetate constant at $50 \mathrm{mM}$, maximum $\mathrm{CaCO}_{3}$ could be obtained at urea concentration ranging from $0.130 \mathrm{~g} / \mathrm{L}$ to $0.170 \mathrm{~g} / \mathrm{L}$, and $\mathrm{NaNO}_{3}$ from $8.8 \mathrm{mM}$ to $10.5 \mathrm{mM} . \mathrm{CaCO}_{3}$ precipitation considerably impeded when the concentration of both factors exceeded the stated range. Otherwise, Figure $4 \mathrm{~b}$ describes the increased in $\mathrm{CaCO}_{3}$ concentration when the concentrations of $\mathrm{NaNO}_{3}$ and sodium acetate in the BG-11 medium were added at range around $8.5 \mathrm{mM}$ to $10.35 \mathrm{mM}$ and $52 \mathrm{mM}$ to $67 \mathrm{mM}$, respectively, while maintaining urea concentration at $0.125 \mathrm{~g} / \mathrm{L}$. From Figure $4 \mathrm{c}$, augmentation of $\mathrm{CaCO}_{3}$ concentration was the result of adding the concentration of urea and sodium acetate between $0.135-0.177 \mathrm{~g} / \mathrm{L}$ and $54-69 \mathrm{mM}$, respectively, when $\mathrm{NaNO}_{3}$ was maintained at the center point.

\subsection{Experimental Validation of the Proposed Model}

The optimal values of the three factors were computed by simultaneously solving Equation (1) and (2) through Design Expert. The optimal levels were as follows: $8.74 \mathrm{mM}$ of $\mathrm{NaNO}_{3}, 61.40 \mathrm{mM}$ of sodium acetate, and $0.143 \mathrm{~g} / \mathrm{L}$ of urea. The theoretical responses for biomass density and $\mathrm{CaCO}_{3}$ precipitates concentration as predicted under the abovementioned conditions were $1.535 \mathrm{~g} / \mathrm{L}$ and $1.150 \mathrm{~g} / \mathrm{L}$, respectively, with a desirability value of 0.979 . Table 7 shows the statistical analysis of the results obtained from the validation run applied to two independent replicates $(N=2)$. The observed responses for biomass and $\mathrm{CaCO}_{3}$ precipitation were $1.517 \mathrm{~g} / \mathrm{L}$ and $1.143 \mathrm{~g} / \mathrm{L}$. Experimental values were well within the $95 \%$ confidence interval of the models' prediction. The proximity of the observed and predicted responses indicates that the regression models were sufficiently accurate and reliable for predicting the biomass production and $\mathrm{CaCO}_{3}$ precipitation of $\mathrm{C}$. vulgaris.

Table 7. Statistical analysis of validation experiments.

\begin{tabular}{ccccccc}
\hline Response & $\begin{array}{c}\text { Predicted } \\
(\mathrm{g} / \mathrm{L})\end{array}$ & $\begin{array}{c}\text { Observed } \\
(\mathrm{g} / \mathrm{L})\end{array}$ & $\begin{array}{c}\text { Standard } \\
\text { Deviation }\end{array}$ & $\begin{array}{c}\text { Standard } \\
\text { Error of } \\
\text { Prediction }\end{array}$ & $\begin{array}{c}\text { 95\% Predicted } \\
\text { Interval Low }\end{array}$ & $\begin{array}{c}\text { 95\% Predicted } \\
\text { Interval High }\end{array}$ \\
\hline $\begin{array}{c}\text { Dry cell weight } \\
\mathrm{CaCO}_{3} \text { concentration }\end{array}$ & 1.535 & 1.517 & 0.080 & 0.058 & 1.397 & 1.672 \\
\hline
\end{tabular}

An average biomass density gained at $1.517 \mathrm{~g} / \mathrm{L}$ points to the capability of this locally isolated $C$. vulgaris to undergo trophic switching by assimilating organic carbon source in the form of sodium acetate. At $12 \mathrm{~h}: 12 \mathrm{~h}$ light and dark photoperiod, the experiment would closely resemble the natural solar exposure of many photoautotrophs, especially those dwell in open pond types of cultivation. Thus, by comparison, the effect of mixotrophic treatment on the propagation of microalgal biomass would be more pronounced since most obligate photoautotrophs would register an average biomass density in the range of less than $1.00 \mathrm{~g} / \mathrm{L}$ [9]. The same illumination cycle was also considered to be optimum for the growth of MICP microalgae based on the calcification experiment of Gloeocapsa sp. [6].

The response surface method (RSM) optimization concerning $\mathrm{CaCO}_{3}$ precipitation by $\mathrm{MICP}$ microalgae was also attempted for other Chlorella species. A more recent study by Irfan et al. [22] took an approach of valorizing cement kiln dust (CKD), a waste by-product of limestone calcination to produce cement, as a substrate for biomineralization by Chlorella kessleri using Bold's Basal Medium 
(BBM). The authors had identified three factors, namely temperature, $\mathrm{pH}$ and experiment time as vital factors influencing the $\mathrm{CaCO}_{3}$ calcification process. Their RSM optimization exercise produced a ceiling of $25.18 \mathrm{~g}$ of $\mathrm{CaCO}_{3}$ by standardizing $50 \mathrm{~g}$ waste $\mathrm{CKD}$ mixed to $130 \mathrm{~mL}$ culture medium. The reported figure was very impressive, considering that very high concentration of calcium ions were initially present in the substrate, which can be anywhere between $30-50 \%$ of the total CKD content. The outcome was possibly complemented by a more refined experimental setup since their work had employed continuous aeration of compressed air: $\mathrm{CO}_{2}$ mixture at fixed $96 \%$ to $4 \%$ ratio and a dedicated Grolux illumination system specifically for promoting plant growth. Though the exact calcium content in CKD was not clearly stated, the authors claimed that a maximum of $96 \%$ calcium was eventually extracted from $\mathrm{CKD}$ to precipitate $\mathrm{CaCO}_{3}$. By determining the calcium content initially found in $12 \mathrm{mM} \mathrm{CaCl}_{2} \cdot 2 \mathrm{H}_{2} \mathrm{O}$ feedstock $(0.481 \mathrm{~g} / \mathrm{L})$ and $1.143 \mathrm{~g} / \mathrm{L} \mathrm{CaCO}$ obtained from the final validation run $(0.458 \mathrm{~g} / \mathrm{L})$, we can establish that the conversion or biomineralization efficiency of $C$. vulgaris in this study stands at $95.2 \%$, which is very much comparable to the biomineralization output induced by C. kessleri.

It was also worth noting that the authors' best $\mathrm{CaCO}_{3}$ yield was achieved at nine days, which was at the onset of stationary phase as similar to $C$. vulgaris used in this study. At various alkaline $\mathrm{pH}$ conditions favoring calcite deposition by $C$. vulgaris, Ramanan et al. [5] also observed that the microalga cultivation usually exhibited the highest values of maximum specific growth rate $\left(\mu_{\max }\right)$ on Day 9-10 ( 0.06 to $0.08 \mathrm{~g} / \mathrm{L} /$ day) but $\mu_{\max }$ then gradually reduced to its lowest on Day 14 . Since the performance of $\mathrm{CaCO}_{3}$ precipitation was observed to increase concomitantly with the cell growth, the duration of C. vulgaris cultivation time was decidedly halted on Day 14 for this study.

From Table 7, the precision of the experimental results was satisfactory with values of the standard deviations for both biomass density, and $\mathrm{CaCO}_{3}$ precipitates were within $5 \%$ and $6 \%$ of the measured averages, respectively. However, as we are dealing with the uncertainties of microbiological system, the breadth of error margin can widely differ from one study to the next. In the cultivation experiments involving five species of Chlorella (C. vulgaris, C. minutissima, C. pyrenoidosa, Chlorella sp. 1, and Chlorella sp. 2) grown in various nutrient medium (i.e., BG-11, BBM, Fog's medium, and $\mathrm{M}_{4} \mathrm{~N}$ medium) for the assessment of biomass evolution and lipid production potential, the standard deviations in Sharma et al. [23] results ranged from as small as $1.2 \%$ up to $4.3 \%$. As for data describing the calcium carbonate precipitation by Chlorella, sometimes it may also be expressed as water hardness (calcium ions) removal from the liquid samples. As per recent findings by Wang et al. [14], the recorded standard deviation of calcium carbonate precipitation, in terms of calcium ions removal by C. vulgaris, ranged between $1.64 \%$ and $12.53 \%$.

\subsection{Scanning Electron Microscopy (SEM) and X-Ray Diffraction (XRD) Analyses}

The $\mathrm{CaCO}_{3}$ precipitates were viewed under SEM to determine the morphological characteristics of the crystals. SEM magnifications of the $\mathrm{CaCO}_{3}$ crystals collected from C. vulgaris are shown in Figure 5. There is a clear appearance of mineral protrusion emerging from the masses of spherical C. vulgaris cells in Figure 5a,b, an association that strongly suggests the cells serving as nucleation sites for $\mathrm{CaCO}_{3}$ crystals formed during the MICP process. Figure $5 \mathrm{c}$, d reveal several of the free-floating fragmented crystals. All in all, the majority of $\mathrm{CaCO}_{3}$ minerals in SEM images distinctly embody a profile that appears layered and rhombohedric in shape, matching the rhombohedral habit of calcite polymorph [24]. Nonetheless, upon closer inspection of Figure 5d, there also appears to be several needle-like crystals seemingly clumped together, a possible indication to aragonite precipitation as well and potentially being the precursor to subsequent calcite formation. 

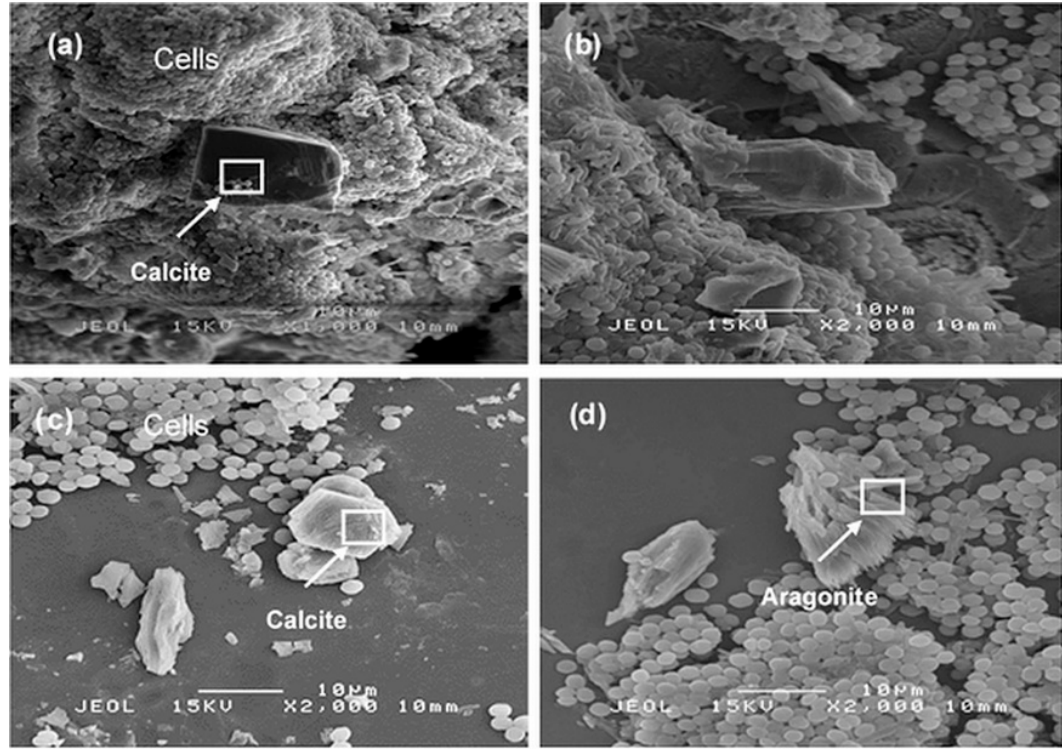

Figure 5. SEM images of $\mathrm{CaCO}_{3}$ crystals formed by C. vulgaris (a) rhombohedric calcite crystal protruding from masses of cells at 1000× magnification, (b) side view of crystal protrusion for masses of cells at $2000 \times$ magnification, (c) free-floating calcite crystals at 2000× magnification, and (d) needle-like crystals possibly aragonite at $2000 \times$ magnification.

The crystallographic properties of $\mathrm{CaCO}_{3}$ precipitates were then further authenticated by powder X-ray diffraction (XRD) analysis. Figure 6a shows the peak patterns of the crystalline structure of $\mathrm{CaCO}_{3}$ minerals obtained from biomineralization activity of $C$. vulgaris. Initially, the finding was compared against spar calcite, geogenic dolomite, and spar aragonite reference diffractograms in Figure $6 \mathrm{~b}$. Alignment to the reference peaks shows that phase compositions in Figure 6a displays the highest peak at $29.5^{\circ}$, which conforms to the characteristic XRD peak of spar calcite. Further confirmation was achieved through comparing the tabulated spectra from this study with powder diffraction file (PDF) of related mineral. The same XRD results characteristically produced the strongest detected $(h k l)$ peaks at $2 \theta$ values of 23.1, 29.5, 36.0,39.5, 43.2, 47.6, 48.6, corresponding to the Miller indices of (012), (104), (110), (113), (202), (018), (116), (122), (214), (300), which are the pure crystallographic planes of calcite, respectively (PDF\# 05-586).

It seems that the crystalline properties and morphology of $\mathrm{CaCO}_{3}$ are very much influenced by the method of synthesis. C. vulgaris, like many photosynthetic microorganisms, follows the "biologically induced-mineralization" (BIM) mechanism whereby $\mathrm{CaCO}_{3}$ crystals are precipitated indirectly from the interactions between the metabolic by-products that were secreted out of cells and the inorganic compounds present in the immediate microenvironment. As such, it is more of a diffusion phenomenon that follows calcium supersaturation in which $C$. vulgaris cells have limited control over composition, localization, and nucleation of $\mathrm{CaCO}_{3}$ crystals. BIM generated $\mathrm{CaCO}_{3}$ precipitates are effectively varied in the size of particulates, crystallinity, and morphology [8]. On the other hand, calcite is widely considered the dominant polymorph in the biomineralization mediated by microalgae. Precipitation of $\mathrm{CaCO}_{3}$ minerals started with the formation of unstable amorphous phase around the cells' locality, which is then transformed to metastable phase aragonite or a lesser degree, vaterite. Further increased in the $\mathrm{pH}$ during photosynthesis and inorganic carbon fixation, deemed most crucial factor for the formation of the polymorph in a constant-composition environment, will favor the final crystal transformation to the more thermodynamically stable phase calcite [25]. 

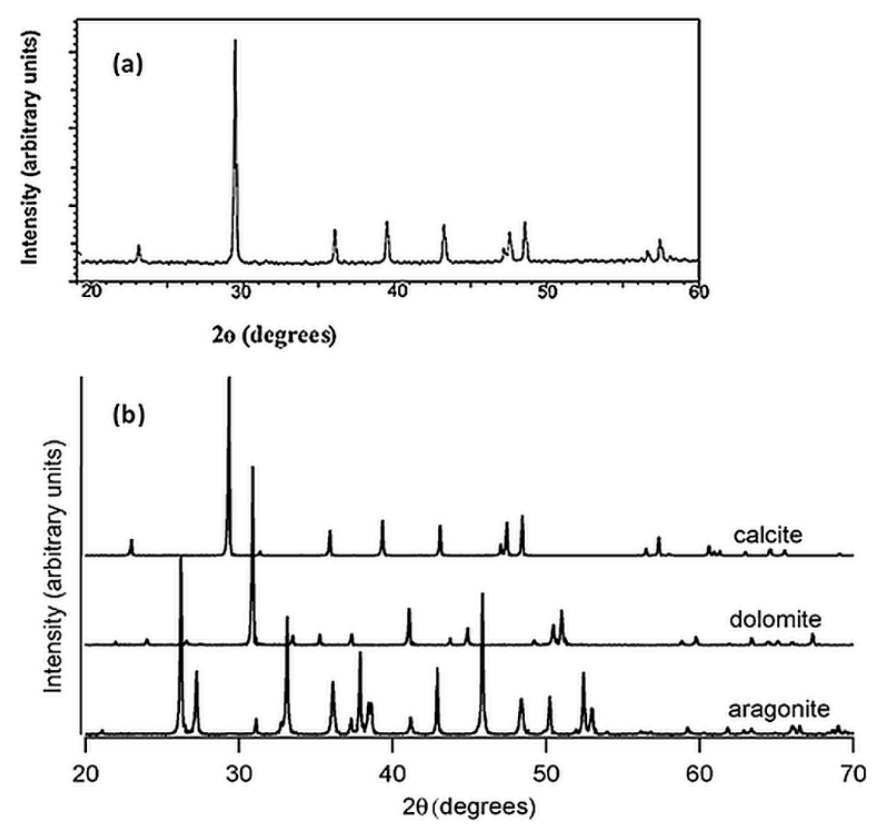

Figure 6. XRD diffractograms of (a) $\mathrm{CaCO}_{3}$ crystals from this study, (b) representative XRD of spar calcite, geogenic dolomite, and spar aragonite.

Other metal ions present in the medium ingredients may also modify the precipitation of different polymorph. It was reported that the presence of $\mathrm{Zn}^{2+}$ ions would slightly lower the microenvironment $\mathrm{pH}$ surrounding the cells, a condition preferring the building of aragonite [26]. Both $\mathrm{Ca}^{2+}$, as well as $\mathrm{Zn}^{2+}$ cations, may be adsorbed onto the negatively charged cell walls. The microalgal nucleation sites which adsorbed $\mathrm{Zn}^{2+}$ enable local enrichment of this ion, whereby their interaction will stabilize the metastable aragonite modification. $\mathrm{Zn}^{2+}$ that strongly adsorbed on aragonite crystals inhibits further transformation to calcite. $\mathrm{Mg}^{2+}$ also demonstrated similar inhibiting effect through adsorption onto the specific growth sites on the crystal surface or by increasing the crystal solubility through incorporation into the calcite lattice [27]. In a comparison study between abiotic and biotic system containing C. vulgaris cells, aragonite was mostly produced in an abiotic solution containing $\mathrm{Mg}^{2+}$ ions of up to $5.0 \mathrm{mM}$. On the contrary, calcite was preferentially produced in the biotic system under the influence of both photoautotrophic and heterotrophic $C$. vulgaris cultures. The profound affinity of adsorption of exopolysaccharide (EPS) released by $C$. vulgaris on the aragonite surface over calcite (possibly due to the presence of carboxylic compounds in the EPS) was attributed to the stronger inhibition of aragonite polymorph formation despite the presence of $\mathrm{Mg}^{2+}$ ions in the medium [13].

\section{Materials and Methods}

\subsection{Microalgae Strain and Inoculum Preparation}

Chlorella vulgaris used throughout this study was originally isolated off the waters of Pulau Sayak Island, Malaysia. Following strain identification, stock culture is maintained by the International Institute of Aquaculture \& Aquatic Science, Universiti Putra Malaysia (I-AQUAS UPM), Malaysia. C. vulgaris from slant agar were transferred to Blue-Green (BG) 11 aquaculture medium [28] and incubated at $25{ }^{\circ} \mathrm{C}$ in an orbital shaker (Ecotron, INFORS-HT, Switzerland) at $110 \mathrm{rpm}$ for 14 days to obtain a cell concentration of approximately $3.3 \times 10^{7}$ cells $/ \mathrm{mL}$. The composition of BG- 11 in $\mathrm{g} / \mathrm{L}$ consisted of the following: $1.5 \mathrm{~g} \mathrm{NaNO}_{3}, 0.04 \mathrm{~g} \mathrm{~K}_{2} \mathrm{HPO}_{4}, 0.075 \mathrm{~g} \mathrm{MgSO} .7 \mathrm{H}_{2} \mathrm{O}, 0.036 \mathrm{~g} \mathrm{CaCl}_{2} .2 \mathrm{H}_{2} \mathrm{O}$, $0.006 \mathrm{~g}$ citric acid, $0.006 \mathrm{~g}$ ferric ammonium citrate, $0.001 \mathrm{~g}$ EDTA (disodium salt), $0.02 \mathrm{~g} \mathrm{Na} 2 \mathrm{CO}_{3}$, and $1 \mathrm{~mL}$ of trace metal mix A5 $(\mathrm{g} / \mathrm{L})\left(2.86 \mathrm{~g} \mathrm{H}_{3} \mathrm{BO}_{3}, 1.81 \mathrm{~g} \mathrm{MnCl}_{2} .4 \mathrm{H}_{2} \mathrm{O}, 0.222 \mathrm{~g} \mathrm{ZnSO}_{4} .7 \mathrm{H}_{2} \mathrm{O}, 0.39 \mathrm{~g}\right.$ $\left.\mathrm{Na}_{2} \mathrm{MoO}_{4} \cdot 2 \mathrm{H}_{2} \mathrm{O}, 0.079 \mathrm{~g} \mathrm{CuSO}_{4} \cdot 5 \mathrm{H}_{2} \mathrm{O}, 0.049 \mathrm{~g} \mathrm{Co}\left(\mathrm{NO}_{3}\right)_{2} \cdot 6 \mathrm{H}_{2} \mathrm{O}\right)$. Illumination was provided through manual installation of T5 fluorescent tubes (OSRAM, Germany) inside the shaker unit, illuminating the 
cultures at about $2280 \pm 250$ lux or an equivalent photosynthetic photon flux (PPF) of $30 \pm 3.3 \mu \mathrm{mol} / \mathrm{m}^{2} \cdot \mathrm{s}$ for a constant diurnal cycle of $12 \mathrm{~h}$ (light): $12 \mathrm{~h}$ (dark). The culture was used as standard inoculums for all cultivations in shake flasks.

\subsection{Selection of Factors in Medium Formulation}

Eight factors $\left(\mathrm{NaNO}_{3}, \mathrm{~K}_{2} \mathrm{HPO}_{4}, \mathrm{MgSO}_{4} .7 \mathrm{H}_{2} \mathrm{O}, \mathrm{ZnSO}_{4} .7 \mathrm{H}_{2} \mathrm{O}\right.$, sodium acetate, urea, temperature, and salinity) were screened for their significances towards growth and MICP-producing capabilities of $C$. vulgaris cultured in BG-11 medium. $\mathrm{NaNO}_{3}, \mathrm{~K}_{2} \mathrm{HPO}_{4}, \mathrm{MgSO}_{4} .7 \mathrm{H}_{2} \mathrm{O}$ and $\mathrm{ZnSO}_{4} .7 \mathrm{H}_{2} \mathrm{O}$ are components initially present in BG-11. These existing nitrogen and major ionic macronutrients were chosen for evaluation as to whether their increment or reduction would have a significant effect on the two responses. Their levels were determined based on Chlorella cultivation data found in the literature. Sodium acetate served as a carbon source while urea stood for nitrogen source as well as feed material for MICP via urea hydrolysis. The range of urea tolerable by $C$. vulgaris strain was previously determined through one-factor-at-a-time (OFAT) experiments [29]. Temperature was the sole exogenous factor chosen. Since $C$. vulgaris is also halotolerant with recognizable desalination ability [30], the impact of salinity was included by adding sodium chloride to mimic the conditions from freshwater to the marine environment.

In this study, $5 \mathrm{mM}$ of $\mathrm{NaHCO}_{3}$ was used as substitute DIC for $\mathrm{Na}_{2} \mathrm{CO}_{3}$ since it is more soluble in water. The supply of $\mathrm{Ca}^{2+}$ ions was provided by $12 \mathrm{mM}$ of $\mathrm{CaCl}_{2} \cdot 2 \mathrm{H}_{2} \mathrm{O}$, respectively. Stock solutions of the selected chemicals were added separately and aseptically to $250 \mathrm{~mL}$ Erlenmeyer flask and topped up with $85 \mathrm{~mL}$ BG-11 medium devoid of chemicals chosen as experimental variables. All mixotrophic cultivations were standardized to $100 \mathrm{~mL}$ by adding $15 \mathrm{~mL}$ of inoculum $(15 \% \mathrm{v} / \mathrm{v})$. Using a $\mathrm{pH}$ meter (Eutech Instrument, Vernon Hills, IL USA), the $\mathrm{pH}$ of the mixture was adjusted to $\approx 7.5$ by the addition of either $0.1 \mathrm{~N} \mathrm{HCl}$ or $\mathrm{NaOH}$. The medium was sterilized by autoclaving at $121^{\circ} \mathrm{C}$ for $15 \mathrm{~min}$. The cultures were incubated in an orbital incubator shaker agitated at $110 \mathrm{rpm}$ for 14 days. All cultivations were carried out in duplicates.

\subsection{Biomass Density}

The microalgal biomass, expressed as dry cell weight per culture volume $(\mathrm{g} / \mathrm{L})$, was determined gravimetrically using the filtration and oven-drying method. After 14 days, $10 \mathrm{~mL}$ of cell culture was vacuum filtered through a pre-weighed dried glass-fiber filter (Sartorius, Germany). $10 \mathrm{~mL}$ of $50 \mathrm{mM}$ $\mathrm{NaHCO}_{3}$ and distilled water were run through the filter twice to wash the cells. Separately, $10 \mathrm{~mL}$ of $1 \mathrm{~N} \mathrm{HCl}$ was added to dissolve the $\mathrm{CaCO}_{3}$ precipitates lodged to the cell suspension [31]. The filtered cells and filter paper were dried in an oven at $70^{\circ} \mathrm{C}$ for $48 \mathrm{~h}$ until a constant weight was obtained.

\subsection{Quantification of $\mathrm{CaCO}_{3}$ Precipitation}

During the filtration process, the filtrate containing dissolved $\mathrm{CaCO}_{3}$ was collected after $10 \mathrm{~mL}$ of $1 \mathrm{~N} \mathrm{HCl}$ was run through the filter [31]. The hydrochloric acid reacted with $\mathrm{CaCO}_{3}$ to form the water-soluble $\mathrm{CaCl}_{2}$, which has a 1:1 molar ratio to $\mathrm{CaCO}_{3}$ in terms of $\mathrm{Ca}^{+}$ion concentration. The concentration of $\mathrm{Ca}^{+}$ion obtained was measured by using ethylenediaminetetraacetic acid (EDTA) titration following the APHA standard method [32]. The molarity of $\mathrm{Ca}^{2+}$ that was present in the filtrate was calculated, as shown in Equation (3). Molarity of $\mathrm{Ca}^{2+}$ was expressed as $\mathrm{CaCO}_{3}$ equivalent. Conversion to $\mathrm{CaCO}_{3}$ concentration (in $\mathrm{g} / \mathrm{L}$ ) was done by multiplying $\mathrm{Ca}^{2+}$ molarity with $\mathrm{CaCO}_{3}$ molecular weight $(100.0869 \mathrm{~g} / \mathrm{mol})$ :

$$
C a^{2+}(\mathrm{M})=\frac{\text { molarity of EDTA } \times \text { titre volume }(\mathrm{mL})}{\text { filtrate volume }(\mathrm{mL})}
$$




\subsection{Scanning Electron Microscopy}

Before SEM examination, the microalgal samples were centrifuged at $5000 \mathrm{rpm}$ (equivalent to relative centrifugal force of $1845 \times g$ ) for 5 min (Microfuge 16, Beckman Coulter, Brea; CA, USA). The supernatant was decanted, and the pellet was fixed with $2.5 \%(v / v)$ glutaraldehyde for 4 to $6 \mathrm{~h}$ at $4{ }^{\circ} \mathrm{C}$. The samples were washed three times, with $0.2 \%(v / v)$ sodium cacodylate buffer for $10 \mathrm{~min}$ each. The samples were then post-fixed with $1 \%(v / v)$ osmium tetroxide for $2 \mathrm{~h}$ at $4{ }^{\circ} \mathrm{C}$ and washed three times with sodium cacodylate buffer for $10 \mathrm{~min}$ each. After post-fixation, the samples were dehydrated gradually using a series of increasing acetone concentrations: $35 \%, 50 \%, 75 \%, 95 \%$ once for $10 \mathrm{~min}$ each, and 100\% three times for 15 min each. After the drying process, the samples were mounted on aluminum stubs and coated with gold using a sputter coater. The samples were then observed using SEM (Model JEOL JSM-6400, Tokyo, Japan) with an accelerating voltage of $15.0 \mathrm{kV}$.

\subsection{X-ray Diffraction Analysis}

The crystalline phase of the $\mathrm{CaCO}_{3}$ produced after 14 days was analyzed by powder X-ray diffraction (XRD). The XRD measurements were conducted on a Shimadzu XRD-6000 Diffractometer equipped with a Cu-tube $(30 \mathrm{kV}, 30 \mathrm{~mA})$. The primary-beam was employed in a $\theta$ range of $2^{\circ}$ to $60^{\circ}$ at $2^{\circ} / \mathrm{min}$.

\subsection{Medium Formulation Through Statistical Design and Modeling}

The eight factors considered were screened at high $(-1)$ and low $(+1)$ preset, as shown in Table 8. Design Expert Version 11.0.5 (Stat-Ease Inc., Minneapolis, MN, USA) was used to design the experimental matrices of both Plackett-Burman Design (PBD) and Box-Behnken Design (BBD), performed ANOVA analysis on the dataset, derivation of polynomial model equations, generation of response surface plots and lastly, prediction of the optimum levels of factors. In PBD, the significant factors identified from the half-normal plot analysis were fitted to the first-order model, as shown in Equation (4):

$$
Y=B_{0}+\sum_{i=1}^{n} B_{i} X_{i}
$$

where $\mathrm{Y}$ is the predicted response, $B_{0}$ the model constant, $X_{i}$ the independent variable, $B_{i}$ the linear coefficient of the variable. Factors deemed significant were then chosen for response surface optimization by BBD method. The total number of experimental runs $(N)$ designed by BBD was based upon the relationship of:

$$
N=2 k^{2}-2 k+C_{p}
$$

where $k$ is the factorial number, and $C_{p}$ is the replications at center points [33]. The outcomes of the experiments were regressed to the second-order polynomial function to correlate the relationship existed between the response and the independent variables, as shown in Equation (6):

$$
Y=B_{0}+\sum_{i=1}^{n} B_{i} X_{i}+\sum_{i<j}^{n} B_{i j} X_{i} X_{j}+\sum_{j=1}^{n} B_{j j} X_{j}^{2}
$$

where $Y$ is the predicted response; $B_{0}$ is the estimated regression coefficient of the fitted response; $X_{i}$ represents the non-coded independent variables. The regression coefficient for the linear term is represented by $B_{i}$ while $B_{i j}$ the second-order interaction, and $B_{j j}$ the quadratic coefficient. 
Table 8. Levels of factors used in Plackett-Burman Design.

\begin{tabular}{ccccc}
\hline & & \multicolumn{3}{c}{ Actual Levels of Coded Factors } \\
\cline { 3 - 5 } Factors & Symbol & $\mathbf{- 1}$ & $\mathbf{0}$ & $\mathbf{+ 1}$ \\
\cline { 3 - 5 } & & 2.5 & 12.25 & 22 \\
$\mathrm{NaNO}_{3}(\mathrm{mM})$ & $\mathrm{A}$ & 0.01 & 0.055 & 0.1 \\
$\mathrm{Urea}(\mathrm{g} / \mathrm{L})$ & $\mathrm{B}$ & 0.00077 & 0.01039 & 0.02 \\
$\mathrm{ZnSO}_{4} .7 \mathrm{H}_{2} \mathrm{O}(\mathrm{mM})$ & $\mathrm{C}$ & 0.1 & 0.8 & 1.5 \\
$\mathrm{MgSO}_{4} .7 \mathrm{H}_{2} \mathrm{O}(\mathrm{mM})$ & $\mathrm{D}$ & 0.07 & 0.2 & 0.33 \\
$\mathrm{~K}_{2} \mathrm{HPO}_{4}(\mathrm{mM})$ & $\mathrm{E}$ & 7.5 & 28.75 & 50 \\
Sodium acetate $(\mathrm{mM})$ & $\mathrm{F}$ & 24 & 27.5 & 30 \\
Temperature $\left({ }^{\circ} \mathrm{C}\right)$ & $\mathrm{G}$ & 0.05 & 15.05 & 30 \\
Salinity $(\mathrm{ppt})$ & $\mathrm{H}$ & & & 3 \\
\hline
\end{tabular}

\subsection{Model Validation Runs}

Experimental runs were carried out in duplicates to confirm the validity of the predicted model. C. vulgaris was cultivated in BG-11 medium under the same cultivation conditions as described previously but with the concentrations of significant factors from BBD following the predicted composition having the highest desirability from Design Expert simulation. The cultures were also cultivated for 14 days. The average responses of the biomass and $\mathrm{CaCO}_{3}$ concentration would be compared with those predicted by the regression models.

\section{Conclusions}

Plackett-Burman Design was employed in this study to screen the eight factors presumed to contribute significant effect towards biomass density and $\mathrm{CaCO}_{3}$ precipitation of microalga C. vulgaris. It was found that the two responses were highly dependent on $\mathrm{NaNO}_{3}$, urea, and sodium acetate. Fine-tuning the formulation of the three components then made use of the RSM variation of Box-Behnken Design. The maximum biomass density of $1.517 \mathrm{~g} / \mathrm{L}$ and $\mathrm{CaCO}_{3}$ mineral concentration of $1.143 \mathrm{~g} / \mathrm{L}$ were observed in BG-11 medium formulated with $8.74 \mathrm{mM}$ of $\mathrm{NaNO}_{3}$, $61.40 \mathrm{mM}$ of sodium acetate, and $0.143 \mathrm{~g} / \mathrm{L}$ of urea, respectively, conforming to the RSM prediction at $95 \%$ confidence level. SEM analysis and elucidation by XRD indicated that calcite was the dominant $\mathrm{CaCO}_{3}$ polymorph formed during the MICP process by C. vulgaris cells.

Author Contributions: Conceptualization M.S.M. and J.S.T.; Methodology, Z.W.C., K.A. and F.W.F.W.; investigation, Z.W.C. and K.A.; resources, M.S.M. and F.W.F.W.; formal analysis, Z.W.C., K.A. and S.E.A.; writing—original draft preparation, Z.W.C.; writing-review and editing, S.E.A. and M.S.M.; supervision, M.S.M., J.S.T. and A.B.A.; funding acquisition, M.S.M. and A.B.A. All authors have read and agreed to the published version of the manuscript.

Funding: This research was funded by UNIVERSITI PUTRA MALAYSIA (UPM-IPM Grant Scheme), grant number (GP-IPM/2017/9551600).

Conflicts of Interest: The authors declare no conflict of interest.

\section{References}

1. Barkia, I.; Saari, N.; Manning, S.R. Microalgae for High-Value Products Towards Human Health and Nutrition. Mar. Drugs 2019, 17, 304. [CrossRef] [PubMed]

2. Van der Ruyt, M.; van der Zon, W. Biological in situ reinforcement of sand in near-shore areas. Proc. Inst. Civ. Eng. Geotech. Eng. 2009, 162, 81-83. [CrossRef]

3. Ariyanti, D.; Handayani, N.A. Hadiyanto Feasibility of Using Microalgae for Biocement Production through Biocementation. J. Bioprocess. Biotech. 2012, 2, 1-4. [CrossRef]

4. Van Paassen, L.A.; Daza, C.M.; Staal, M.; Sorokin, D.Y.; van der Zon, W.; van Loosdrecht, M.C.M. Potential soil reinforcement by biological denitrification. Ecol. Eng. 2010, 36, 168-175. [CrossRef] 
5. Ramanan, R.; Kannan, K.; Deshkar, A.; Yadav, R.; Chakrabarti, T. Enhanced algal $\mathrm{CO}_{2}$ sequestration through calcite deposition by Chlorella sp. and Spirulina platensis in a mini-raceway pond. Bioresour. Technol. 2010, 101, 2616-2622. [CrossRef] [PubMed]

6. Bundeleva, I.A.; Shirokova, L.S.; Pokrovsky, O.S.; Bénézeth, P.; Ménez, B.; Gérard, E.; Balor, S. Experimental modeling of calcium carbonate precipitation by cyanobacterium Gloeocapsa sp. Chem. Geol. 2014, 374-375, 44-60. [CrossRef]

7. Zhu, T.; Dittrich, M. Carbonate precipitation through microbial activities in natural environment, and their potential in biotechnology: A review. Front. Bioeng. Biotechnol. 2016, 4, 4. [CrossRef] [PubMed]

8. Castro-Alonso, M.J.; Montañez-Hernandez, L.E.; Sanchez-Muñoz, M.A.; Macias Franco, M.R.; Narayanasamy, R.; Balagurusamy, N. Microbially induced calcium carbonate precipitation (MICP) and its potential in bioconcrete: Microbiological and molecular concepts. Front. Mater. 2019, 6, 126. [CrossRef]

9. Medipally, S.R.; Yusoff, F.M.; Banerjee, S.; Shariff, M. Microalgae as Sustainable Renewable Energy Feedstock for Biofuel Production. Biomed Res. Int. 2015, 2015, 519513. [CrossRef]

10. Perez-Garcia, O.; Escalante, F.M.E.; de-Bashan, L.E.; Bashan, Y. Heterotrophic cultures of microalgae: Metabolism and potential products. Water Res. 2011, 45, 11-36. [CrossRef] [PubMed]

11. Mohamed, M.S.; Tan, J.S.; Kadkhodaei, S.; Mohamad, R.; Mokhtar, M.N.; Ariff, A.B. Kinetics and modeling of microalga Tetraselmis sp. FTC 209 growth with respect to its adaptation toward different trophic conditions. Biochem. Eng. J. 2014, 88, 30-41. [CrossRef]

12. Harun, R.; Singh, M.; Forde, G.M.; Danquah, M.K. Bioprocess engineering of microalgae to produce a variety of consumer products. Renew. Sustain. Energy Rev. 2010, 14, 1037-1047. [CrossRef]

13. Kawano, M.; Hwang, J. Biochemical Effects of the Unicellular Green Alga Chlorella vulgaris on the Precipitation Rates and Polymorphism of Calcium Carbonate Minerals. Clay Sci. 2010, 14, 219-227.

14. Wang, P.; Hu, Q.; Yang, H.; Cao, J.; Li, L.; Liang, Y.; Wang, K. Preliminary study on the utilization of $\mathrm{Ca}^{2+}$ and $\mathrm{HCO}_{3}{ }^{-}$In karst water by different sources of Chlorella vulgaris. Carbonates Evaporites 2014, 29, 203-210. [CrossRef]

15. Xu, P.; Fan, H.; Leng, L.; Fan, L.; Liu, S.; Chen, P.; Zhou, W. Feasibility of microbially induced carbonate precipitation through a Chlorella-Sporosaricina co-culture system. Algal Res. 2020, 47, 101831. [CrossRef]

16. Ravindran, B.; Kassim, M.A.; Mohamed, M.S. Screening of medium constituents for the cultivation of Scenedesmus dimorphus UTEX 1237 using 2k factorial design approach. IOP Conf. Ser. Mater. Sci. Eng. 2020, 716, 12003. [CrossRef]

17. Goulding, K.H.; Merrett, M.J. The photometabolism of acetate by Chlorella pyrenoidosa. J. Exp. Bot. 1966, 17, 678-689. [CrossRef]

18. Schwenk, J.R. Effects of Magnesium Sulfate, Digestate, and Other Inorganic Nutrients on The Phototrophic Growth of The Green Microalgae S. dimorphus. Master's Thesis, Cleveland State University, Cleveland, $\mathrm{OH}$, USA, 2012.

19. Xie, T.; Xia, Y.; Zeng, Y.; Li, X.; Zhang, Y. Nitrate concentration-shift cultivation to enhance protein content of heterotrophic microalga Chlorella vulgaris: Over-compensation strategy. Bioresour. Technol. 2017, 233, 247-255. [CrossRef]

20. Bin Halmi, M.I.E.; Abdullah, S.R.S.; Wasoh, H.; Johari, W.L.W.; Ali, M.S.b.M.; Shaharuddin, N.A.; Shukor, M.Y. Optimization and maximization of hexavalent molybdenum reduction to Mo-blue by Serratia sp. strain MIE2 using response surface methodology. Rend. Lincei 2016, 27, 697-709. [CrossRef]

21. Abu, M.L.; Nooh, H.M.; Oslan, S.N.; Salleh, A.B. Optimization of physical conditions for the production of thermostable T1 lipase in Pichia guilliermondii strain SO using response surface methodology. BMC Biotechnol. 2017, 17, 78. [CrossRef]

22. Irfan, M.F.; Hossain, S.M.Z.; Khalid, H.; Sadaf, F.; Al-Thawadi, S.; Alshater, A.; Hossain, M.M.; Razzak, S.A. Optimization of bio-cement production from cement kiln dust using microalgae. Biotechnol. Rep. 2019, 23, e00356. [CrossRef] [PubMed]

23. Sharma, A.K.; Sahoo, P.K.; Singhal, S.; Patel, A. Impact of various media and organic carbon sources on biofuel production potential from Chlorella spp. 3 Biotech 2016, 6, 1-12.

24. Al Omari, M.M.H.; Rashid, I.S.; Qinna, N.A.; Jaber, A.M.; Badwan, A.A. Calcium Carbonate. In Profiles of Drug Substances, Excipients and Related Methodology; Academic Press Inc.: Cambridge, MA, USA, 2016; Volume 41, pp. 31-132. 
25. Ogino, T.; Suzuki, T.; Sawada, K. The formation and transformation mechanism of calcium carbonate in water. Geochim. Cosmochim. Acta 1987, 51, 2757-2767. [CrossRef]

26. Santomauro, G.; Baier, J.; Huang, W.; Pezold, S.; Bill, J. Formation of Calcium Carbonate Polymorphs Induced by Living Microalgae. J. Biomater. Nanobiotechnol. 2012, 3, 413-420. [CrossRef]

27. Davis, K.J.; Dove, P.M.; De Yoreo, J.J. The role of $\mathrm{Mg}^{2+}$ as an impurity in calcite growth. Science 2000, 290, 1134-1137. [CrossRef]

28. Rippka, R.; Deruelles, J.; Waterbury, J.B. Generic assignments, strain histories and properties of pure cultures of cyanobacteria. J. Gen. Microbiol. 1979, 111, 1-61. [CrossRef]

29. Arumugam, K.; Rosfarizan, M.; Ashari, S.E.; Mohamed, M.S. Screening of Microalgae Strains Capable to Induce Calcium Carbonate Precipitation as a Potential Source of Biomineral. In Proceedings of the Asian Federation of Biotechnology Malaysia Chapter International Symposium 2019, Putrajaya, Malaysia, 20-23 October 2019; Ramli, N., Ibrahim, M.F., Kamal-Bahrin, E., Manan, F.A., Ibrahim, Z., Zainal, N.S.L.M., Zolkefli, N., Eds.; AFOB Malaysia: Putrajaya, Malaysia, 2019; p. 94.

30. Figler, A.; B-Béres, V.; Dobronoki, D.; Márton, K.; Nagy, S.A.; Bácsi, I. Salt Tolerance and Desalination Abilities of Nine Common Green Microalgae Isolates. Water 2019, 11, 2527. [CrossRef]

31. Takano, H.; Furu-une, H.; Burgess, J.G.; Manabe, E.; Hirano, M.; Okazaki, M.; Matsunaga, T. Production of ultrafine calcite particles by coccolithophorid algae grown in a biosolar reactor supplied with sunlight. Appl. Biochem. Biotechnol. 1993, 39-40, 159-167. [CrossRef]

32. APHA. Standard Methods for the Examination of Water and Wastewater, 21st ed.; Eaton, A.D., Clesceri, L.S., Franson, M.A.H., Rice, E.W., Greenberg, A.E., Eds.; American Public Health Association: Washington, DC, USA, 2005.

33. Hassan, M.Z.; Sapuan, S.M.; Roslan, S.A.; Aziz, S.A.; Sarip, S. Optimization of tensile behaviour of banana pseudo-stem (Musa acuminate) fibre reinforced epoxy composites using response surface methodology. J. Mater. Res. Technol. 2019, 8, 3517-3528. [CrossRef]

Sample Availability: Samples of the compound are not available from the authors.

(C) 2020 by the authors. Licensee MDPI, Basel, Switzerland. This article is an open access article distributed under the terms and conditions of the Creative Commons Attribution (CC BY) license (http://creativecommons.org/licenses/by/4.0/). 